\title{
Legal Protection For Consumers From Misleading Information On Goods And Services In The Perspective Of Consumers Protection Laws
}

\author{
Gde Oka Wisnumurti; Ni Wayan Arwati; Simon Nahak; I Made Sepud \\ Magister of Law, Postgraduate Program Warmadewa University, Denpasar, Bali
}

\begin{abstract}
The study examines the forms of legal protection for consumers from misleading information on goods and/or services in the Decision Number 391/Pid.B/2016/PN.Dps; and criminal liabilities of business actors for the misleading information on goods and/or services in terms of the provisions of Law Number 8 of 1999 concerning Consumer Protection in Decision Number 391/Pid.B/2016/PN.Dps. The study is designed by using empirical legal design and the issues are explored based on the condition of gaps between das sollen 'expectation' and das sein 'reality'. The approaches used in this study are case approach, statute approach, and empirical approach. The results of this study showed that legal protection for the consumers from misleading information regarding goods and/or services is stipulated through legislation that is Law Number 8 of 1999 concerning Consumer Protection, especially in the articles governing advertising in the Consumer Protection Act, those are Article 9, Article 10, Article 12, Article 13, Article 17, and Article 20. Thus, the rights and interests that have been stipulated are given protection and legal certainty for consumers. Criminal liabilities of business actors against the misleading information about goods and/or services when viewed from Law Number 8 of 1999 concerning Consumer Protection are adjusted to the form of criminal liability that can be borne by the business actors and/or their administrators on the condition that the offense committed can be proven.
\end{abstract}

Keywords: Legal Protection, Goods and/or Services, Misleading Information

\section{Introduction}

Consumer protection is an integral part of fair business activities. In fair business activities, there is a balance of legal protection between consumers and producers. The dearth of balanced protection will make the consumers remain defenseless. Losses suffered by the consumers can arise as a result of legal relationships in the agreements between producers and consumers, as well as a consequence of the acts against the law committed by producers.

In conveying information, business actors should necessarily provide and complete the information correctly so that there are no important things that should be hidden from consumers which should be their rights. Any information provided must also be understood (easily) because if not, they will remain unuseful. Incomplete and incorrect information that is 
conveyed to the consumers can create a misleading impression on consumers, causing them to feel cheated. If it is examined in more depth, such as in the context of Indonesia, until now special regulations, which are equivalent to the laws governing the advertising activities, have not been established. Consequently, pluralisms in the advertising provisions in the applicable positive law often occur, for example as stipulated in the Law Number 8 of 1999 concerning Consumer protection, Civil Code, Criminal Code, Government Regulations, and Ministerial Regulations that are Administrative in nature. As a consequence, this condition leaves a number of issues relating to the determination of the rights and obligations of advertising business actors, prohibited forms of advertising deception, the burden of liabilities of advertising business actors, the position of the Indonesian Advertising Board as the advertising supervisory agency, until the sanctions that can be brought together to the business actors if they violate the provisions in question [1].

In this regard, consumers need to be given special protection from the dissemination of misleading information about advertisements on goods and services. Regulations governing consumer protection are absolutely necessary because of the weak position of the consumers compared to that of business actors, which regarding the process of producing the products to the stage of distribution of the intended products or services, consumers are never involved at all, so that they are always in a position of disadvantaged entity.

Previously, this study have been conducted by some studies, such as in [2] which aims to determine the legal protection of consumers over misleading television commercials. The findings in this study is the legal protection for consumers over misleading ads on television that there are two kinds: (1) protection of consumer law preventative which can be done through legislation/regulation that is by providing the rule of law which will ensure that consumers can receive and legal protection through better consumer control of the government, the public, as well as by non-governmental consumer protection agency, and (2) Consumer Protection repressive laws, the legal protection given to consumers in the event of a dispute between businesses and consumers as a result of lawsuits from consumers who feel aggrieved. Two ways that can be passed through the judiciary to file a lawsuit to the judiciary in the domicile of the consumer or through non- judicial namely through the Consumer Dispute Settlement Board (BPSK). In addition, (Paramita and Kasih, 2017) conducted the similar study which is focused on legal protection for consumer related to a misleading advertisement in consumer protection perspective and the businesses' accountability for consumer related to the misleading advertisement. The results of this study showed that forms of legal protection that can be given to consumers for misleading advertisements in Consumer Protection Act (Undang-Undang Pelindungan Konsumen), namely by the provisions in Chapters III Article 4 to Article 7 concerning the rights and obligations of business actors and consumers, there are restrictions on business actors in advertising their products contained in Article 9, Article 10, Article 12, Article 13 and Article 17. Other forms with the establishment of the National Consumer Protection Agency regulated in Chapter VIII Consumer Protection Act (Undang-Undang Pelindungan Konsumen) from Article 31 to Article 43. The liability of business actors for misleading advertisements is contained in Consumer Protection Act (Undang-Undang Pelindungan Konsumen) specifically contained in Article 20 and the verification system is regulated in Article 22 and Article 28. The principle of liability contained in Consumer Protection Act (Undang-Undang Pelindungan Konsumen) is direct or absolute responsibility set forth in articles 7 through article 11 and above expressly stated in article 19 paragraph (1) Consumer Protection Act (Undang-Undang Pelindungan Konsumen). Another similar conducted by (Setiawan, Ferdi, and Faniyah's study, 2018). The focus of their study is the form of legal protection of the consumer for misleading housing ad information 
and the business actor's responsibility for misleading home advertising information. As a result of analysis, it was shown that firstly, forms of legal protection of misleading housing ad information, for the actions undertaken by developers PT. Bangun Persada Sejatera to Villa Anggrek housing consumer, the consumer as an injured party can make various legal efforts to fight for his rights through: the settlement of consumer dispute through litigation and settlement of non-litigation consumer disputes. Secondly, the business actor's responsibility for misleading housing advertising information is that the consumer is entitled to submit his/her complaint relating to the house in the maintenance warranty period of 100 (one hundred) calendar days. Developers as business actors will seek every improvement that complained by consumers. If the consumer feels aggrieved by the business actors, the entrepreneur shall be obliged to provide compensation, compensation and/or reimbursement for loss caused by the user, user and the utilization of the goods and/or services that have been traded. Motivated by the reality of the dealings between the consumers and producers as described above, this study is conducted to examine the forms of legal protection for the consumers from the circulation of misleading information by the producers, as well as to reveal the forms of liabilities of producers regarding the misleading information conveyed to the consumers.

\section{Methods}

This present study applied empirical legal design. In this case, the issues are explored based on the condition of gap between das solen and das sein, that is gap between the theoretical state and legal facts in society takes place. The gap in question is a frequent violation of the provisions of article 4 letter $\mathrm{c}$ in the Consumer Protection Act, which stipulates that the consumer rights are the right to true, clear, and truthful information regarding the condition and guarantee of goods and/or services. Unfortunately, the fact that is most often perceived in the field is that there is still a lot of information about goods and/or services purchased by consumers that are not in accordance with what they exactly expect, one of it is food that has expired, misleading advertisements, and conditions of goods that are not feasible. Thus, the provisions of Article 4 of the Consumer Protection Act are violated. The implication is that the gap between theory, legal provisions, and practices occurred in the community. The approaches used in this study are the case approach, statute approach, and empirical approach. The data sources used are primary data and secondary data. Data collection techniques applied are interview technique and document study technique. The research location is in Pengadilan Negeri Denpasar Kelas I A located in Denpasar City, Bali Province. The data of this study are processed by using qualitative data analysis technique, in which, the data obtained are presented descriptively.

\section{Results And Discussion}

Based on analysis conducted in examining the forms of legal protection for consumers from misleading information on goods and/or services in the Decision Number 391/Pid.B/2016/PN.Dps; and criminal liabilities of business actors for the misleading information on goods and/or services in terms of the provisions of Law Number 8 of 1999 
concerning Consumer Protection in Decision Number 391/Pid.B/2016/PN.Dps. Therefore, the results of this study are discussed in the following description.

\subsection{Legal Protection for Consumers from Misleading Information on Goods and/or Services}

The role of law in the economic context is to create a competitive economy and market. In this regard, there is no producer or business actor dominates the market as long as the consumer has the right to freely choose a product. The consumers and the business actors have an interdependent relationship with each other. Without the consumers, the business actors cannot guarantee the continuity of their business. Conversely, without the production results of business actors, the consumers cannot meet their needs [5].

The business practices between business actors and consumers often place the consumers in a powerless position. This defenseless position results from the absence of intervention of the consumers in the production process until the results formed to an item and/or service. Therefore, legal protection for consumers is very noteworthy (Syawali and Imaniyati, 2010). The Consumer Protection is regulated in a number of Legislative Regulations but specifically (Lex Spesialis) regulations regarding consumer protection are stipulated in Law Number 8 of 1999 concerning Consumer Protection.

In Article 10 of the Consumer Protection Act, it is stipulated that "Business actors, in offering goods and/or services intended for trading, are prohibited from offering, promoting, advertising or making false or misleading statements regarding:

1. Price or fare of an item and/or service;

2. The utility of an item and/or service;

3. Conditions, security, guarantees, rights or compensation for an item and/or service;

4. Discounts or attractive prizes offered;

5. The danger of using the goods and/or services

Strictly speaking, the provisions in Chapter IV of the Law on consumer protection prohibit businesses from marketing their products if they are not in accordance with the promises included in the label, etiquette, information, advertisements or promotions, including in the statement of legalisation [7].

Other regulations governing the issue of advertising other than those contained in the Consumer Protection Act, are:

1. Law Number 18 of 2012 concerning Food;

2. Law Number 40 of 1999 concerning the Press; and

3. Government Regulation of the Republic of Indonesia Number 69 of 1999 concerning Food Labels and Ads.

Article 44 specifies: "every advertisement for traded food shall contain information about food correctly and not misleading, either in the form of pictures and/or sounds, statements, and/or other forms." Whereas, regarding the consistency of labels with the condition of contents it is specified: "Sentences, words, signs, names, symbols, logos, images and so on contained in labels or advertisements, shall be in accordance with the origin, nature, content, composition, quality, or utility of food."

In that situations, it is necessary to have strict rules and regulations regarding advertising so that the information delivered through advertising can actually be used as a guide for consumers in choosing and purchasing goods and/or services appropriately. Strict regulation is a manifestation of government instruments to guarantee legal protection for the consumers [1]. Moreover, according to the theory of Legal Protection proposed by Philipus M. Hadjon, the legal protection is a collection of rules or regulations that will protect something from other 
things. Hence, the law provides protection for the rights of consumers from something that results in not fulfilling their rights.

With the rules and regulations on advertising, at least, it brings some benefits that will be obtained by the consumers, as follows [1]:

a. The consumer choice of alternatives will be better if consumers get more information from the market.

b. If the consumers could obtain better information, product quality tends to experience improvements, in response to changing consumers' needs and preferences.

c. The decrease in prices due to reduced strength of seller's market information.

A good arrangement of advertising should be able to accommodate the interests of various parties involved in order to be able to run in tune and harmony. The company has an interest in the ads it makes leaving a deep impression on consumers. Advertisers have an interest so that advertisements ordered from the advertising companies can increase the sales of advertised products and the advertising consumers play an important role in obtaining the accurately correct product information [1].

\subsection{Criminal Liability of Business Actors on Misleading Advertisements}

The Consumer Protection Act contains many criminal provisions, including those stipulated in the liability of criminal business actors. This can be seen in Article 61 of the Consumer Protection Act which states that criminal charges can be applied to business actors and/or their administrators. With this provision, it means that the business entities (legal entities or not legal entities, private or public companies, cooperatives and so on) can be submitted as defendants in a criminal case, in addition to those who work as administrators [8]. Thus, criminal liability can be applied to business actors and/or administrators if the elements of the offenses they committed can be proven.

The criminal threats to the business actor or its administrators are stated in Article 62 paragraph (1), which among others are maximum imprisonment of 5 years or a maximum fine of Rp. 2,000,000,000 (two billion rupiahs), if it breaks the rules of the provisions contained in Articles 8, 9, 10,13, 15, 17 paragraph (1) letters a, b, c, e and paragraph (2), and Article 18. Likewise in Article 62 paragraph (2) which stipulates that offences on Article 11, 12, 13 paragraph (1), 14, 16 and Article 17 paragraph (1) letters $d$ and f, are subject to a maximum imprisonment of 2 years in prison or a maximum fine of Rp. 500,000,000 (five hundred million rupiahs). Whereas for violations, which are committed by business actors and/or administrators, resulting in consumers being seriously injured, seriously ill, permanently disabled, or dying, the applicable criminal provisions are imposed, that is stipulated in Article 62 paragraph (3) of the Consumer Protection Act.

In accordance with criminal provisions in the Consumer Protection Act, business actors can be held liable for their acts if they have indeed been proven to have committed a crime. The criminal threat can be in the form of a prison sentence or by paying a fine imposed in accordance with the mistake made. In the Consumer Protection Act, the important things about promotion and the meaning of promotion are regulated. Article 1 number 6 of the Consumer Protection Act contains the following provisions: "Promotion is an activity of introducing or disseminating information on an item and/or service to attract consumers' purchase interests of goods and/or services that will be and are being traded".

Advertising is one medium of information that plays a crucial role in the framework of the promotion or marketing of a product. Advertising has a very close relationship with the business world, in that, it becomes a way for business actors to introduce their products to consumers. Without advertising, business people will not be able to sell their products 
optimally and effectively, while on the other hand, the consumers will not have sufficient information about products available on the market if advertisements are not distributed. If this happens, the industrial world and modern economy will definitely be powerless [9]. Advertising media can be divided into three types, as follows [7]:

a. Oral media;

b. Print media, such as newspapers, magazines, brochures, pamphlets, leaflets;

c. Electronic media, such as television, radio, computers or the internet; and

d. Promotion with advertisements that only take very short time can also increase turnover/income in a company.

As stated by Zaim Saidi, in the context of Indonesia, this practice in advertising is quite difficult. The consumer protection law is a part of consumer law that contains principles or governing rules and also contains properties that protect the interests of the consumers. In general and fundamentally, the relationship between business actors and consumers is a continuous and continuous relationship. This relationship occurs because both of the parties do need each other and have a high degree of dependence between one another. This situation is systematically utilized by the business actors in a distribution and marketing system of goods or services to achieve a certain level of productivity and effectiveness in order to achieve business objectives. To a certain extent, the distribution of these products results in a mass relationship. Because of its mass nature, the role of the state is very necessary in order to protect the interests of the consumers in general. Correct and accountable advertising information can help consumers to make the right choices in accordance with their needs and abilities. The reasonable ways of marketing will support the consumers' choice decisions that benefit to themselves. The majority of consumers in Indonesia are still too vulnerable to absorb unfair information on the advertising of the goods and services that is very risky. If adequate supervision is not provided and consumers are left to weigh up and decide on what ads are worthy of being trusted, the big risks will be felt by these consumers.

The Consumer Protection Act is based on benefits, justice, balance, consumer safety and security, and legal certainty. Various rules and regulations relating to consumer protection efforts are basically the same as other regulations whose provisions contain ideas or concepts that may be classified as abstract, which ideally include ideas about justice, certainty, and usefulness as expressed by [10].

Regarding the product information content, of course, the party most responsible is the business actor as the party producing the goods and/or services. In the Consumer Protection Act, the possibility of holding parties accountable for advertising activities has been adjusted to these two possibilities. For example, for business actors it is possible for situations based on provisions in the parties in Article 19 Paragraph (1) of the Consumer Protection Act, as follows: "Business actors are responsible for providing compensation for damage, pollution and/or consumer losses due to consuming goods and/or services that are produced, or traded.

For business players of advertising or advertising media, the obligation to be liable is contained in Article 20 of Act Number 8 of 1999 concerning Consumer Protection, that is that advertising business actors are liable for the advertisements produced and all the consequences of those advertisements. The effort to hold parties accountable in advertising activities is not an easy matter to implement.

Therefore, the liability is based on two considerations, such as:

a) Advertising activities involve many economic actors, in this case, advertiser entrepreneurs (producers, distributors, suppliers, and retailers), advertising entrepreneurs, professional advertising organizations, and advertising media. In addition, it also involves consumers as recipients of information presented through advertisements, and the government; 
b) The place of advertising itself in legal proceedings in Indonesia is grouped more in the sector of state administrative law, especially in the group of the press law.

\section{Conclusions}

Based on the discussion above, the results found can be concluded that 1) legal protection for consumers from misleading information on goods and/or services is based on laws and regulations, which in this case is Law Number 8 of 1999 concerning Consumer Protection, especially in the Articles governing advertisements in Consumer Protection Act, including Article 9, Article 10, Article 12, Article 13, Article 17, and Article 20. Thus, the rights and interests that have been regulated will be protected as well as the existence of legal certainty for the consumers. 2) criminal liability of business actors for misleading information on goods and/or services viewed from Law Number 8 of 1999 concerning Consumer Protection based on criminal liability that can be borne by the business actors and/or their administrators if the elements of their offences can be proven. The criminal threat to the business actor or its management is stipulated in Article 62 paragraph (1), which among others, are a maximum imprisonment of 5 years or a maximum fine of $\mathrm{Rp} 2,000,000,000$ (two billion rupiahs), if it violates the provisions contained in the articles $8,9,10,13,15,17$ paragraph (1) letters a, b, c, e and paragraph (2), and Article 18. Likewise in Article 62 paragraph (2) stipulates that violations of Article 11, 12, 13 paragraph (1), 14, 16 and Article 17 paragraph (1) letters $d$ and $f$, shall be threatened with a maximum imprisonment of 2 years in prison or a maximum fine of $\mathrm{Rp} \mathrm{500,000,000} \mathrm{(five} \mathrm{hundred} \mathrm{million} \mathrm{rupiahs).}$

\section{References}

[1] D. Harianto, Perlindungan Hukum bagi Konsumen terhadap Iklan yang Menyesatkan. Bogor: Ghalia Indonesia, 2010.

[2] P. Mahadewi, "Perlindungan Hukum Konsumen Atas Tayangan Iklan Televisi Yang Menyesatkan," Ratu Adil J. Huk. dan Kebijak. Sos., vol. 3, no. 1, pp. 1-9, 2014.

[3] I. G. A. I. D. D. P. Paramita and D. P. D. Kasih, "Perlindungan Hukum Terhadap Konsumen Terkait Iklan Yang Menyesatkan Ditinjau Berdasarkan Undang-Undang Perlindungan Konsumen Dan Kode Etik Periklanan Indonesia," Kertha Semaya, vol. 5, no. 2, pp. 1-5, 2017.

[4] B. Setiawan, Ferdi, and I. Faniyah, "Perlindungan Hukum Terhadap Konsumen Atas Informasi Iklan Perumahan Yang Menyesatkan Dalam Perjanjian Kepemilikan Rumah Pada PT. Bangun Persada Sejahtera," vol. 1, no. 1, pp. 1-12, 2018.

[5] C. T. S. Kristianti, Hukum Perlindungan Konsumen. Jakarta: Sinar Grafika, 2008.

[6] H. Syawali and N. S. Imaniyati, Hukum Perlindungan Konsumen. Bandung: Mandar Maju, 2010.

[7] N. H. . Siahaan, Hukum Konsumen Perlindungan Konsumen dan Tanggung Jawab Produk. Jakarta: Panta Rei, 2005.

[8] A. Nasution, Hukum Perlindungan Konsumen Suatu Pengantar. Jakarta: Diadit Media, 2001

[9] F. Jefkins, Periklanan. Jakarta: Erlangga, 1997.

[10] G. Radbruch, Menguak Tabir Hukum. Jakarta: Chandra Pratama, 1996. 